\title{
О НЕКОТОРЫХ АСПЕКТАХ ФОРМИРОВАНИЯ РАННЕНЕОЛИТИЧЕСКОЙ ПОСУДЫ ЗАПАДНОЙ СИБИРИ
}

\author{
(c) 2020 B.A. 3ax \\ ФИЦ Тюменский научный центр СО РАН
}

Статья поступила в редакцию 29.09.2020

\begin{abstract}
Исследование в Западной Сибири новых ранненеолитических лесостепных и таежных памятников актуализирует вопросы происхождения и развития гончарства. Плоскодонная и круглодонная неолитическая посуда в Западной Сибири схожа по форме и орнаментации и выглядит как продукт развития уже существующей, привнесенной керамической традиции. Судя по радиоуглеродным датам, на западно-сибирских территориях эта посуда появляется в пределах VII тыс. до н.э. Придерживаясь версии заимствования местным населением керамического производства у мигрантов, полагаем, что в формировании западно-сибирской керамики важным моментом являлась имитация-перенос конструктивных деталей берестяных емкостей. Так, в рельефных элементах (карнизики, наплывы и валики на внешней и внутренней стороне венчиков керамических сосудов) можно усмотреть соответствие обручам и элементам их крепления на берестяной посуде. На наш взгляд, постепенно рельефные элементы на глиняной посуде, вероятно, преобразуются в семантические: волнистые линии (зигзаги) на наплывах с внутренней стороны венчика уже не только «передают» следы крепления обруча, но и, видимо, связаны с образом воды (волны) как содержимого сосуда.

Ключевые слова: Западная Сибирь, Тоболо-Ишимье, неолит, плоскодонная и круглодонная посуда, карнизики, валики, наплывы с внутренней стороны венчика.
\end{abstract}

DOI: $10.37313 / 2658-4816-2020-2-4-102-121$

Работа выполнена по госзаданию - проект № АAАA-A17-117050400147-2.

\section{Введение}

На лесостепной и таежной территории Западной Сибири наряду с неолитическими материалами с круглодонными сосудами ${ }^{1}$ известны открытые позднее комплексы с круглодонной и плоскодонной посудой ${ }^{2}$, датированные, по последним данным, ранним неолитом - концом VII кал. тыс. до н.э. ${ }^{3}$ Занимаемые западно-сибирским неолитическим населением территории находились практически на равноудаленном расстоянии от обоих основных (ближневосточный и дальневосточный) центров происхождения гончарства, обобщающие характеристики которых приведены Ю.Б. Цетлиным

Зах Виктор Алексеевич, доктор исторических наук, заведующий сектором археологических и природных реконструкций.E-mail:viczakh@mail.ru и Н.Ю. Петровой ${ }^{4}$. Вопросы происхождения, развития, периодизации, культурной принадлежности и хронологии некоторых комплексов западно-сибирского неолита до сих пор окончательно не решены, но исследователи, считающие, что керамическое производство или его идея были привнесенными, отправным районом видят ближневосточный центр.

На появление в Западной Сибири глиняной посуды имеется три основные точки зрения. Первым из исследователей, считавшим, что население Урала (восточноуральская неолитическая культура) восприняло от южных соседей «умение делать глиняную посуду», был О.Н. Бадер 5 . По его мнению, «посуда древнейшего этапа (козловского. - B.3.) отличается вполне сложившимися 
техникой, формами и орнаментацией, что говорит против ее самостоятельного, местного возникновения» ${ }^{6}$. Появление керамики на северных территориях Западной Сибири, по Л.Л. Косинской, стало результатом процесса культурной диффузии, заимствования керамической технологии на последней стадии «процесса, начавшегося еще в период неолитической революции на Ближнем Востоке»7. Правда, исследователь считает возможным принять идею миграции боборыкинского населения, повлиявшего на развитие «амнинского, кошкинского и сатыгинского культурных типов» по восточным склонам Урала, из района исходного формирования в лесостепном Притоболье 8 Открытые в последнее десятилетие в Барабинской лесостепи ранненеолитические комплексы с плоскодонной посудой В.И. Молодин с коллегами считают автохтонным продуктом9 . В.Т. Ковалева с открытием комплексов с плоскодонной и круглодонной посудой предложила для зауральского неолита двухлинейную схему развития: автохтонная линия представлена козловскими и полуденковскими материалами, и связанная с мигрантами - кошкинскими и боборыкинскими группами, которые расселились из южных, но различных регионов Восточной Европы. Кошкинская посуда, по мнению В.Т. Ковалевой, имеет наибольшее сходство с керамикой Прикаспия ${ }^{10}$, а боборыкинская - с посудой поздненеолитических комплексов Кавказа ${ }^{11}$.

Мы исходя из имеющихся западно-сибирских материалов полагаем, что формирование неолита происходило в процессе прямого взаимодействия мигрантов - носителей керамических традиций из прилегающих к ближневосточному центру областей и еще не знавшего гончарства населения Западной Сибири ${ }^{12}$. Первопричиной миграции в восточном направлении скорее всего являлись экологические последствия климатических событий во время аридных фаз мангышлакской регрессии в период 9,3-8,5 тыс. л.н. ${ }^{13}$ В связи с этим центр миграционного процесса мог находиться на прикаспийских или сопредельных с ними территориях. Судя по количеству (более 50 памятников, по В.Т. Ковалевой и С.Ю. Зыряновой, а по нашим данным, с учетом не введенных в научный оборот, - значительно больше) уже открытых в Западной Сибири ранненеолитических поселений поток мигрантов был довольно существенным, а со временем, с продвижением на север и восток, население только увеличивалось.

В результате в некоторых районах Западной Сибири формируются неолитические комплексы, в которых как нигде на сопредельных территориях этого времени присутствует оригинальная керамика с рельефными элементами: карнизиками, валиками и наплывами с внешней или внутренней стороны венчиков. Бесспорно, отдельные из отмеченных морфологических элементов встречаются в незначительных количествах и на керамике различных регионов Евразии в разные хронологические периоды, но своеобразие западно-сибирских комплексов заключается в существовании и развитии этих элементов оформления в рамках раннего и среднего этапов неолита. Мы полагаем, что рельефные элементы в комплексах с плоскодонной и круглодонной посудой и материалах с круглодонной посудой могли появиться в процессе слияния культур мигрантов и аборигенного западно-сибирского населения путем переноса некоторых элементов оформления с берестяных емкостей на глиняные сосуды.

Прослеживаемые на широком круге источников самобытность и своеобразие западно-сибирской неолитической посуды выделяют ее среди синхронных комплексов сопредельных территорий. Наличие указанных рельефных элементов позволяет достаточно четко очертить ареал комплексов с данной посудой (рис. 1). Западная граница проходит по восточному склону Урала, на севере граница отмечена комплексами Амня 1 в бассейне р. Казым ${ }^{14}$ и Ет-то 1 на Надым-Пуровском водоразделе ${ }^{15}$. На юге граница ареала находилась, вероятно, на степной территории Тургайского проги- 
ба $^{16}$, в правобережной части Прииртышья (поселение Борлы, Алексеевка 1 и др.) $)^{17}$. Восточная граница определяется по керамике Самусьского могильника в Томском Приобье, изылинской посуде, имеющей наплывы с внутренней стороны венчика, в Новосибирском Приобье и на р. Ине в Присалаирье ${ }^{18}$. По некоторым элементам орнамента (овальные вдавления) и наплывам с внутренней стороны венчика эти керамические комплексы близки к материалам поселения Автодром 2/2 в Барабе ${ }^{19}$, а также к козловской посуде Приишимья и Притоболья ${ }^{20}$. Комплексы с подобной посудой оригинальны, выделяются среди других за- падно-сибирских неолитических материалов, такая керамика безусловно узнаваема и позволяет с достаточно большой точностью очертить границы, которые, с одной стороны, показывают территории предполагаемого взаимодействия аборигенного населения и мигрантов, с другой - пути расселения представителей уже «симбиозных» традиций.

\section{Материалы и методика исследования}

Материалом исследования послужили керамические коллекции раннего и развитого неолита поселений лесостепной и таежной части Западной Сибири, включаю-

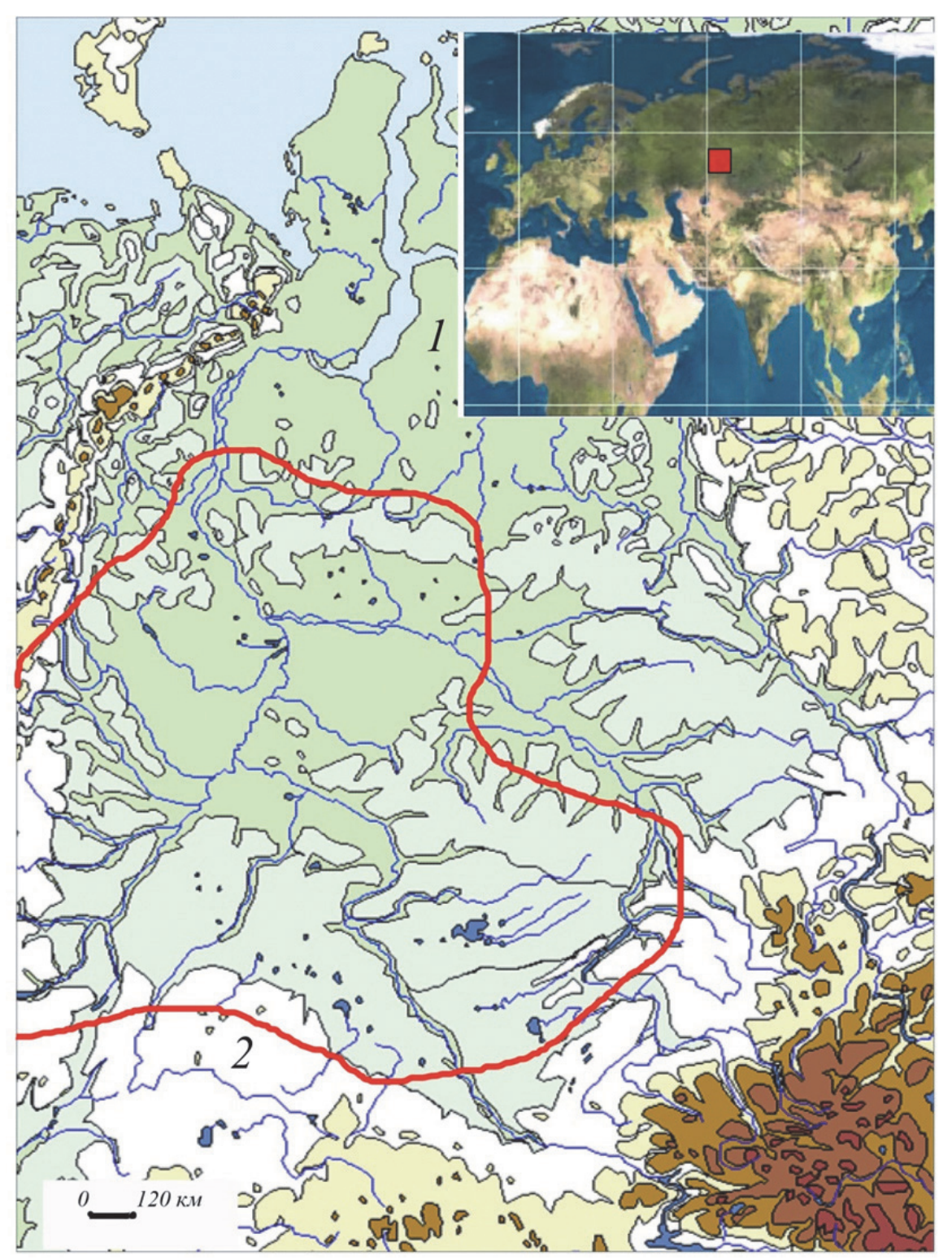

Рис. 1. Ареал западно-сибирской неолитической посуды с рельефными элементами: 1 - в Северной Евразии; 2 - в Западной Сибири 
щие плоскодонную и круглодонную посуду с рельефными элементами. Однако среди этих комплексов есть многослойные, в связи с чем возникает трудность разделения их (в числе таких можно назвать, например, Ук 6, Шайдурихинское 5, ЮАО 15 и др.) на «полуденские, козловские, кошкинские древности, поскольку типологические характеристики их нечеткие» ${ }^{21}$. С другой стороны, на основе различия рельефных и плоскостных узоров выделяются как самостоятельные культурные образования, например, сатыгинский, амнинский, басьяновский и другие типы керамики ${ }^{22}$, что позволяет описать ее многообразие, но не способствует пониманию культурно-исторической ситуации. Во избежание разночтения в интерпретации исследователями одних и тех же комплексов полагаем возможным адаптировать предложенную нами ранее периодизационную схему развития неолита Тоболо-Ишимья (единая линия развития, предполагающая преемственную связь двух культур ранней боборыкинской с боборыкинским и кошкинским этапами и средненеолитической полуденковской с козловским и полуденковским этапами) $)^{23}$ для территории Западной Сибири. Считаем, что при рассмотрении обозначенной нами темы требуется более обобщенный взгляд на анализируемые материалы, поэтому предлагаем объединить их с учетом формы сосудов: плоскодонные и круглодонные и только круглодонные - и наличия на них рельефных элементов (карнизиков, валиков и наплывов). Такой подход объективен и представляется в данном случае целесообразным. В силу вышесказанного в работе не берутся во внимание неолитические комплексы, в которых отсутствуют явно выраженные рельефные элементы: быстринские, кокуйские и артынские, а также материалы, выходящие за пределы указанного хронологического диапазона ${ }^{24}$.

Комплексы раннего неолита с плоскодонной и круглодонной посудой. Датируются концом VII - рубежом VI кал. тыс. до н.э., что подтверждается полученными одиноч- ными датами и сериями дат с однослойных поселений, например Юртобор 3, Мергень 6 в Приишимье и комплекс Тартас 1 в Барабе ${ }^{25}$. Это поселения Притоболья, горнолесного Зауралья, Конды, бассейна Казыма, Среднего Приобья, Прииртышья и Барабы ${ }^{26}$.

Комплексы развитого неолита с круглодонной посудой (середина VI - середина V кал. тыс. до н.э.). Включают козловские материалы поселений на Андреевском озере и в Приишимье, кокшаровско-юрьинские, евстюнихинские, полуденковские в горнолесном и лесостепном Зауралье, еттовские в Надым-Пуровском междуречье и изылинские комплексы в Приобье и Присалаирье ${ }^{27}$.

Для сравнения рельефных элементов на керамике и берестяной посуде в качестве модельных привлечены образцы берестяных емкостей из этнографических коллекций обских угров ${ }^{28}$ и археологических комплексов Нижнего Приобья ${ }^{29}$ и Хакасии (сосуд из экспозиции Государственного Эрмитажа). Мы отдаем себе отчет в том, что круг этих источников объективно ограничен и выводы из такого сопоставления будут носить лишь гипотетический характер. Однако игнорировать саму возможность таким образом попытаться объяснить своеобразие рассматриваемых ранненеолитических комплексов, на наш взгляд, тоже нельзя.

Известно, что в некоторых исследованиях глиняной посуды обусловленность приемов и характера орнаментации связывается с имитацией, т.е. «осознанным или неосознанным воспроизведением в декоре сосуда конструктивных элементов, характерных для другого материала или предмета» ${ }^{30}$. Этот «метод» «имитативного» декора применялся исследователями при изучении текстильной (ложнотекстильной) орнаментации посуды III-II тыс. до н.э. ${ }^{31}$ Указывается, что, с одной стороны, подобный перенос мог быть следствием технологического процесса, с другой - в декоре сосуда воспроизводились определенные черты предмета или материала ${ }^{32}$.

Аналогичный перенос, скорее всего осознанный, отмечается, например, на гли- 
няной посуде раннего железного века, на которой оформлены линии раскройки и стежки сшивания кожаных сосудов ${ }^{33}$.

Наличие на неолитической глиняной посуде таких элементов, как валики на внешней поверхности горловины, наплывы с внутренней стороны венчика, карнизики под срезом с внешней или внутренней стороны венчика, может свидетельствовать, по нашему мнению, о «заимствовании» конструктивных составляющих именно берестяных емкостей. Нет веских оснований связывать эти элементы с технологическими приемами, дополнительными средствами укрепления формы сосуда. Во-первых, они присутствуют не на всей посуде комплексов. Во-вторых, для укрепления горловин сосудов эпохи неолита и раннего металла часто использовался обвязочный шнур, выгоревшие канальцы от которого зафиксированы на венчиках кипринской посуды в Верхнем Приобье ${ }^{34}$ и Присалаирье ${ }^{35}$, ранней неолитической керамики поселений Мергень 5 и 6 в Приишимье ${ }^{36}$, Тартас 1 в Бара$6^{37}$ и андреевской культуры в Притоболье ${ }^{38}$. В-третьих, даже если предположить, что наплывы и валики использовались с целью придания жесткости форме сосуда, это не исключает возможность имитации, поскольку обручи под венчиком, по тулову и дну берестяных емкостей также служили для формирования и закрепления формы изделий. На имитацию же может косвенно указывать и орнамент в виде насечек, наклонных линий, зигзагов под краем венчика, по валикам под венчиком и дну, не несущий технологической нагрузки.

Несомненно, и нам это известно, что рельефные элементы на керамической посуде бытуют достаточно широко территориально и хронологически, в том числе на территории лесостепи Западной Сибири. Например, они встречаются во II тыс. до н.э. в виде валиков на ташковской, кротовской посуде и карнизиков и валиков на федоровской ${ }^{39}$ и позднее - на бакальской керамике ${ }^{40}$. В связи с этим отметим, что появление рельефных элементов, как и в раннем неолите, наблю- дается на фоне миграционного процесса и при преобладании в комплексах плоскодонной посуды. Не исключено, что появление таких элементов может «маркировать» как раз местный этнический субстрат - аборигенное население, продолжающее изготовлять берестяные емкости.

\section{Обсуждение и результаты}

Судя по современным радиоуглеродным данным керамика на территории Западной Сибири появляется приблизительно во второй половине - конце VII кал. тыс. до н.э., что коррелируется с этапом увлажнения и началом подъема кривой сухого периода (8,2-5,5 кал. тыс. л.н.) по геохимическим показателям из донных отложений оз. Кыртыма $^{41}$. Из нижней части разреза жилища поселения Юртобора 3 происходит дата УПИ

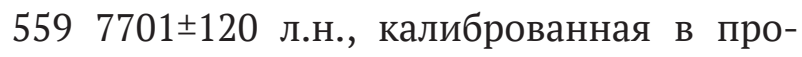
грамме OxCal3 и с вероятностью $1 \sigma(68 \%)$ имеющая значение 6660-6420 кал. л. до н.э., т.е. вторая половина VII тыс. до н.э. ${ }^{42}$

Палеоклиматическая обстановка, в которой обитало автохтонное мезолитическое население и появились носители керамической посуды, отличалась пониженным среднегодовым температурным фоном и повышенной влажностью относительно современных показателей. Учитывая это можно предположить, что современная граница лесостепи была смещена к югу. Количество мезолитических комплексов в Западной Сибири увеличилось по сравнению с палеолитическими, которые связаны с местонахождениями мамонтовой фауны и расположены в современной лесостепной зоне ${ }^{43}$ (кроме местонахождения Луговское под г. Ханты-Мансийском $\left.{ }^{44}\right)$.

Близким к мезолитическому времени является комплекс Черноозерье $2^{45}$, который датирован по кости лошади, происходящей из слоя погребенной почвы, временем $10526 \pm 44$ л.н. ${ }^{46}$ В основном мезолитические памятники исследованы в Среднем Зауралье, бассейнах рек Конды, Исети, Ишима и Иртыша ${ }^{47}$. Для конструкций мезолитического поселения Леуши 9 
имеются радиоуглеродные даты по углю, отобранному с пола сооружений: $7420 \pm 80$, $7560 \pm 80,7510 \pm 80,7590 \pm 80$ л.н. ${ }^{48}$, которые близки по времени неолитическим поселениям Юртобор 3 и Ташково 1 (7701ะ120, $7440 \pm 60$ л.н. соответственно ${ }^{49}$. Как видим, мезолитические и ранненеолитические комплексы на территории Зауралья хронологически сопоставимы.

Какова была бытовая утварь, в частности емкости для хранения жидкости и приготовления пищи, у населения Западной Сибири мезолитического времени, археологические материалы ответа не дают. Однако известно, что во многих докерамических обществах, например в Северной Сирии и Ираке, существовала посуда из камня ${ }^{50}$, а в Чатал Хююке в Анатолии - деревянные сосуды, форма которых с появлением керамики продолжала влиять на форму керамической посуды ${ }^{51}$.

В Западной Сибири для изготовления посуды наиболее подходящим материалом с пребореального периода голоцена были дерево и береста. В бескерамических комплексах на рассматриваемой территории для работы с этими материалами присутствуют все необходимые орудия: ножи, резцы, резчики, скобели, проколки и острия с крутой ретушью. Бесспорным свидетельством использования бересты, скорее всего, в раннем неолите для изготовления емкостей, в частности берестяных коробок и, возможно, лодки, являются находки на Чертовой Горе ${ }^{52}$. Этот факт, а также археологические берестяные емкости, относящиеся к разным хронологическим периодам, пусть и в небольшом количестве, этнографическая и современная берестяная посуда говорят о более чем 7000-летней истории изготовления изделий из бересты. Нет оснований сомневаться в изготовлении берестяной посуды при наличии материала (береста) и специализированных каменных орудий в мезолите. Как в историческое и в настоящее время, в древности из бересты могли мастерить изделия разных размеров и назначения: коробки для сухих продук- тов, водонепроницаемые сосуды, кузова, туеса и детские колыбели ${ }^{53}$.

При всем разнообразии форм и способов создания берестяных емкостей, как правило, общим является прием формирования устья, дна, а иногда и тулова с помощью одного или нескольких деревянных обручей, сделанных из веток черемухи или других видов кустарников и вшитых в загиб устья или пришитых поверх тулова или дна изделия. В загибе устья, на дне и тулове обруч крепился с помощью различных специально подготовленных материалов: распущенных корней, прутьев или сухожилий. Независимо от того, мужчины или женщины в древности изготовляли берестяную посуду, традиция складывалась с раннего времени, а некоторые технологические приемы и нюансы могли переноситься на сосуды из глины с началом появления керамики.

Наряду с аборигенным мезолитическим населением участником процесса становления неолита в Западной Сибири, на наш взгляд, являлись мигранты, принесшие достаточно развитое керамическое производство. Ранее мы отмечали, что исследователи, считающие, что керамическая посуда появилась в результате диффузии или была принесена в Западную Сибирь мигрантами, говорили о ближневосточном центре ее происхождения. Так, О.Н. Бадер считал, что южноуральское население заимствовало глиняную посуду из северных районов Средней Азии, «где рано возникла кельтеминарская неолитическая культура ${ }^{54}$. Керамика раннего дарьясайского этапа культуры по некоторым формам посуды и элементам орнамента сопоставима с ранними зауральскими комплексами, но это сходство, скорее всего, эпохального характера $^{55}$. Основываясь на более поздней позиции боборыкинских материалов по отношению к кошкинским, В.Т. Ковалева и С.Ю. Зырянова считают, что боборыкинские материалы близки поздненеолитическим комплексам Кавказа ${ }^{56}$, а кошкинские аналогичны материалам поселения Джангар из Прикаспия ${ }^{57}$. 
Население носителей плоскодонной и круглодонной посуды каких памятников в Западной Сибири считать появившимися раньше, сказать однозначно сложно. По нашему мнению, это могли быть носители боборыкинской посуды, оставившие поселения в горнолесном Зауралье и ТоболоИшимье. К ним, вероятно, относится ряд поселений, среди которых мы выделяли Юртобор 3, Мергень $3^{58}$, а В.Т. Ковалева и С.Ю. Зырянова ${ }^{59}$ - значительно большее количество поселений, которые, с одной стороны, не выходят за пределы рассматриваемого нами комплекса с плоскодонной и круглодонной посудой, но с другой - вероятно, различаются хронологически (мы имеем в виду хронологическую разницу между боборыкинскими и кошкинскими комплексами при выше обозначенной последовательности), что отмечается в различных соотношениях орнаментов ${ }^{60}$ и валиков ${ }^{61}$. Наиболее ранними среди боборыкинских памятников исследователи считают (хотя различия между группами не всегда отчетливы) поселения Шайдурихинское 5, Ук 6, ЮАО 15, Байрык 1Д, более поздними - Боборыкино 2, Ташково 1, Геологическое 16, ЮАО 5, 9, 12, а самым поздним, по их мнению, является поселение Двухозерное 1, на котором отсутствует басьяновская посуда и фиксируется значительное количество посуды без орнаментов и с разреженными и несложными элементами ${ }^{62}$.

В свое время мы отмечали, что характерной чертой боборыкинской посуды является наличие неорнаментированных по тулову сосудов, количество которых на разных памятниках варьируется от 3,6\% (УстьСуерка 4) до 39,6\% (ЮАО 5). На поселениях Мергень 3 и Юртобор 3 их - 27,6\% и 21,9\% соответственно. Одним из ранних признаков можно считать орнамент в виде мелких неглубоких ямочных вдавлений, отмеченный более чем на 1/5 боборыкинских сосудов. K ранним, видимо, относятся узоры (горизонтальная линия, зигзаг, волна), выполненные в прочерченной технике. В какой-то степени ранним показателем может служить незна- чительная доля сосудов, орнаментированных гребенчатыми оттисками, в основном «качалкой». Некоторые комплексы (Двухозерное 1, Усть-Суерка 4, ЮАО 15) содержат большой процент посуды, украшенной одинарной и раздвоенной отступающей палочкой, что более сближает их с кошкинскими комплексами, чем с боборыкинскими материалами памятников Юртобор 3, Мергень 3 и Пикушка $1^{63}$. В считающихся нами ранними боборыкинских комплексах присутствуют единичные фрагменты керамики, сопоставимой с кошкинской, басьяновской, гребенчатой, сумпаньинской, сатыгинской посудой и прочими типами керамики, которые впоследствии в разных сочетаниях образуют представительные серии. Так, например, на поселении Шайдурихинское 5 отмечаются боборыкинская, басьяновская и сатыгинская посуда, на поселении Нижнее Озеро 3 - кошкинская, сумпаньинская и сатыгинская, на Мергене 6 - посуда боборыкинского, кошкинского, басьяновского, сатыгинского облика и сосуды с гребенчатым орнаментом ${ }^{64}$. Наличие сатыгинской посуды в комплексе поселения Нижнее Озеpo 3 по стратиграфическим наблюдениям и результатам радиоуглеродного датирования позволило исследователям говорить как минимум о двух группах валиковой керамики ${ }^{65}$. Но если принять во внимание, что на поселении Мергень 6 совместно с сатыгинской присутствует и боборыкинская посуда, то это подтверждает существование, с одной стороны, ранних боборыкинских материалов, а с другой - только одной группы валиковой посуды на поселениях с многокомпонентными плоскодонными и круглодонными комплексами. Собственно в боборыкинских комплексах (Юртобор 3, Мергень 3, Пикушка 1 и другие) с характерными чертами, отмеченными нами выше, которые, по нашему мнению, являются наиболее ранними по отношению ко всем остальным неолитическим материалам, валики не обнаружены. Отсутствуют они и на посуде поселений Тентексор, Джангар, Каиршак 1, и на керамике сероглазовской 
культуры Северного Прикаспия ${ }^{66}$ В полупустынных и степных районах Северного Прикаспия в комплексах с плоскодонной и круглодонной посудой встречаются рельефные элементы в виде наплывов с внутренней стороны венчиков на сосудах, например, Джангарской, Варфоломеевской и Орловской стоянок ${ }^{67}$.

Отсутствие валиков на посуде из Прикаспия позволяет высказать предположение, что керамика с валиками на поселениях Борлы ${ }^{68}$ и Алексеевка $1^{69}$ в Павлодарском и Алтайском Прииртышье находит аналоги в многокомпонентных комплексах с плоскодонной и круглодонной посудой Зауралья. На смену ей в Павлодарском Прииртышье приходит посуда с отступающе-ямочным орнаментом, подобная керамике из Железнинского могильника ${ }^{70}$ и поселений Пеньки $1,2^{71}$. Судя по найденным на территории Тургайского прогиба аналогичным многокомпонентным керамическим комплексам, по мнению И.В. Шевниной, можно говорить «о проникновении носителей неолитических культурных традиций лесного Зауралья на территорию обитания маханджарского населения» ${ }^{72}$.

Анализируя неолитические керамические комплексы с сопредельных Западной Сибири территорий, можно констатировать, что рельефные элементы на западносибирской посуде - вероятнее всего, местное явление, связанное с взаимодействием культур аборигенного и пришлого населения, в том числе с возможной имитацией некоторых элементов берестяных емкостей на глиняной посуде. Процесс взаимодействия, судя по рельефным элементам: карнизикам, валикам и наплывам - был растянутым во времени и имел три фазы развития (зарождения и формирования, подъема и спада) в соответствии с законами развития систем ${ }^{73}$.

Необходимо понимать, что огромная территория Западной Сибири была не только слабо, но и неравномерно заселена до прихода носителей керамической посуды. Мигрирующее население, проникающее за Урал, было не единым в этническом плане. Скорее всего, поэтому на территории Зауралья и северных территориях в комплексах с плоскодонной и круглодонной посудой встречается разное сочетание и соотношение керамических типов, т.е. культурные и брачные связи осуществлялись между разными группами населения. При установившихся культурных и брачных отношениях в разные хронологические периоды рельефные элементы с берестяных емкостей переносили только на ту керамическую посуду, которая изготовлялась, как нам представляется, в смешанных союзах аборигенов с мигрантами.

На разных этапах взаимодействия преобладают определенные формы рельефных элементов. В некоторых ранних комплексах с плоскодонной и круглодонной посудой рельефные элементы отсутствуют, например, на керамике поселений Пикушка 1 и Мергень 3, на других (Юртобор 3) появляются небольшие наплывы и карнизики. Так, из 68 сосудов (по венчикам) Юртобора 3, на 5 (7,3\%) присутствуют рельефные элементы. На трех сосудах - карнизик с внутренней или наружной стороны венчика или дна с насечками или без них (рис. 2, 1-5, 7), в двух случаях отмечается небольшой наплыв под краем с внутренней стороны венчика ${ }^{74}$. Иногда карнизик, как на сосуде с поселения Чепкуль 5, значительно массивнее стенки (рис. 2, 6). В комплексах, в которых выделяется несколько керамических типов (боборыкинский, кошкинский, сатыгинский, басьяновский и гребенчатый), в разных сочетаниях встречаются различные формы верхнего края венчика и небольшие наплывы с внутренней стороны под краем венчика. По сравнению с предшествующей (боборыкинской) на рассматриваемой посуде меняется соотношение рельефных элементов. Исчезают карнизики, увеличивается количество наплывов на внутренней стороне венчиков, они становятся массивнее и вытянутее к низу, появляются валики - они встречаются на глиняной посуде в комплексах бассейна р. Конды, горнолесного Зауралья и в Тоболо-Ишимье. 


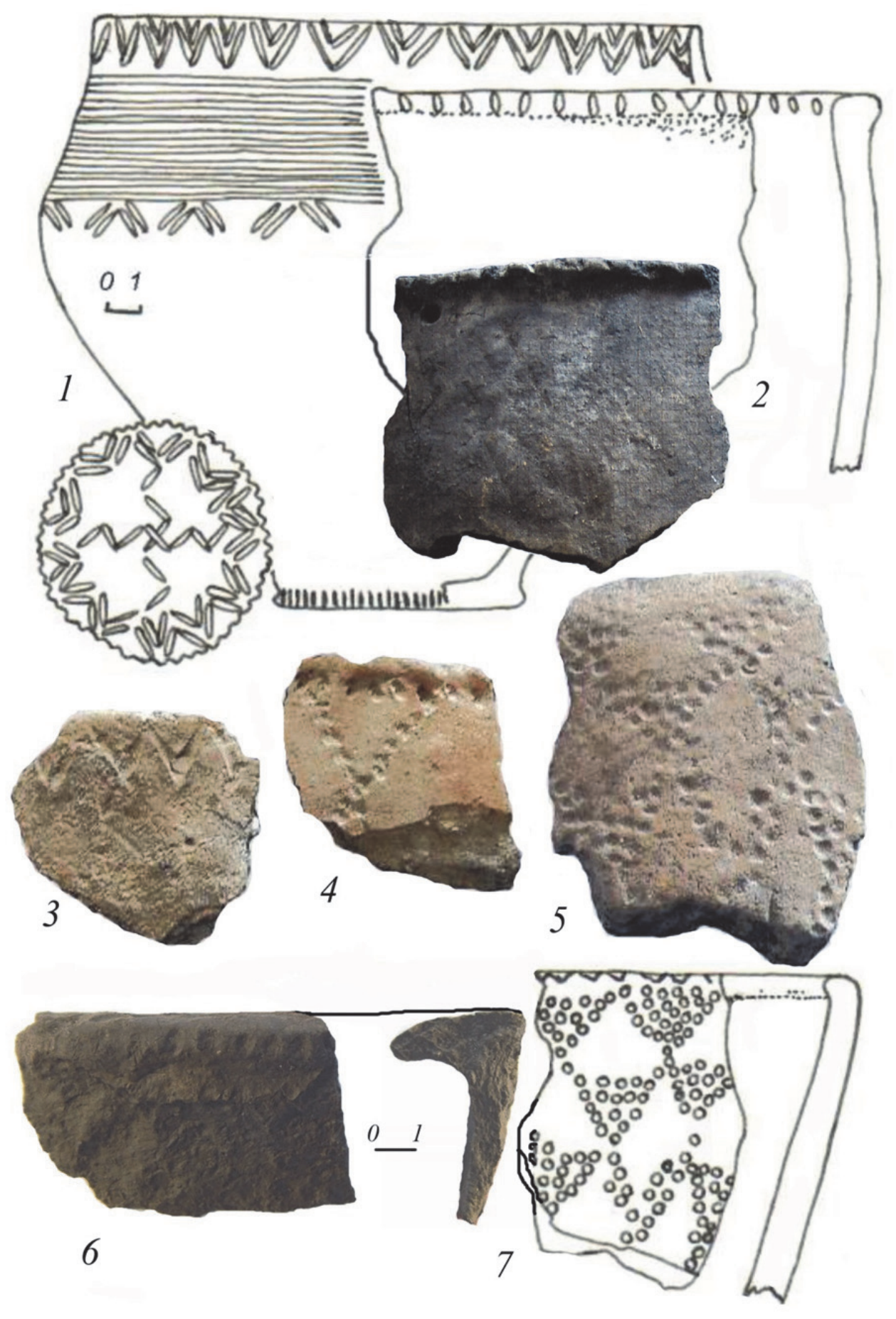

Рис. 2. Плоскодонная и круглодонная керамика с карнизиками. 1-5, 7 - Юртобор 3; 6 - Чепкуль 5

Впервые сатыгинский тип керамики, на сосудах которого присутствуют от одного до нескольких формованных, реже - налепных валиков с наклонно нанесенными на них оттисками овальных вдавлений, был выделен Л.П. Хлобыстиным по материалам поселений Сумпанья 4, $6^{75}$. Сосуды с валиками (7 фр. из 176 сосудов) в комплексе Сумпаньи $6^{76}$ составляют 3,9\%. О количественном содер- жании валиковой посуды в разновременном керамическом комплексе поселения Сумпанья $4^{77}$ судить сложно, но, по данным Л.П. Хлобыстина, из 15 (в другом варианте - 23) фрагментов ямочно-валиковых сосудов валики были на 5, т.е. составляли $33,3 \%$ (или 21,7\%) комплекса соответственно ${ }^{78}$. На поселении Нижнее Озеро 3 валики присутствуют на 31,1\% всего керамического 

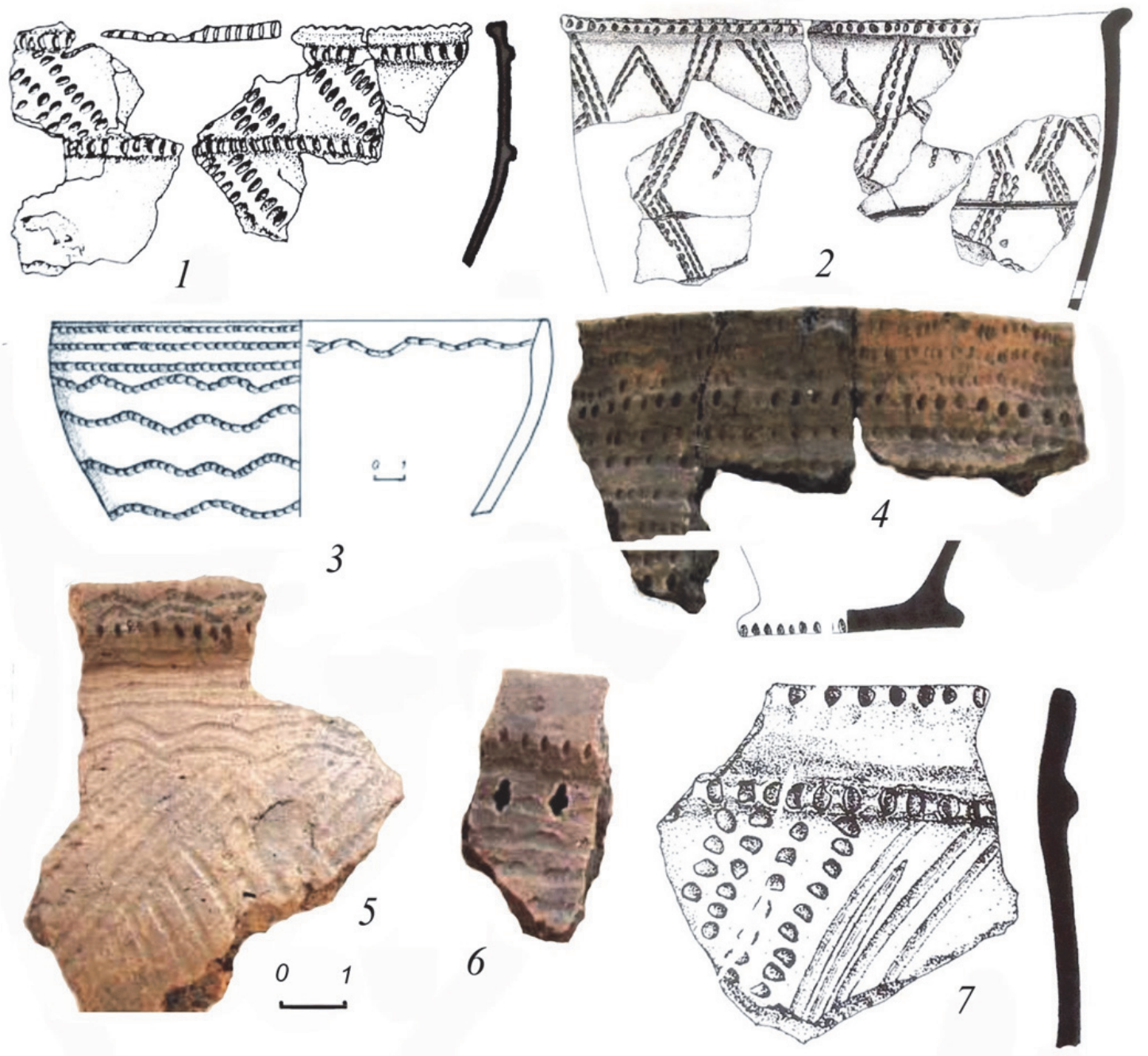

Рис. 3. Плоскодонная и круглодонная керамика с карнизиками, наплывами и валиками.

1 - Сумпанья 6; 2 - Геологическое 16; 3-6 - Мергень 6;

7 - Полуденка 1 (1, 2, 7 - по: Ковалева, Зырянова, 2010)

комплекса, в котором, по мнению авторов, присутствуют сатыгинский, кошкинский и сумпаньинский типы посуды ${ }^{79}$. Наряду с керамикой бассейна р. Конды, горнолесного и лесостепного Зауралья валики встречаются на ранненеолитической посуде Приишимья. В керамическом комплексе Мергень 6 присутствует посуда, напоминающая боборыкинскую, кошкинскую, а также сатыгинский и басьяновский типы керамики, и сосуды с гребенчатой орнаментацией; из них преобладающими являются боборыкинская, кошкинская и смешанные группы керамики (75,25\%), сатыгинская и басьяновская группы и сосуды с гребенкой вместе составляют $24,75 \%$, из которых валики отмечаются на $21,3 \%$ посуды ${ }^{80}$.
В некоторых случаях в комплексах на одних и тех же сосудах присутствуют наплывы с внутренней стороны (рис. 3, 3) и валики, которые в основном двух видов: узкие, рельефно выраженные (рис. 3, 1, 2, 7), и валики на венчиках, достаточно аморфные, оплывшие, округлых форм, напоминающие «воротничок» (рис. 3, 4-6). На валики, как правило, нанесены насечки, иногда - наколы.

Следующий этап развития неолита на рассматриваемых ранее территориях представлен памятниками в комплексах, в которых посуда уже вся круглодонной формы, преимущественно с закрытым устьем, вначале - с небольшими, а впоследствии - с достаточно массивными наплывами с внутренней стороны венчика. 
В основном это материалы кокшаровскоюрьинских, евстюнихинских, козловских, полуденковских и, на наш взгляд, еттовского типа ${ }^{81}$ поселений. На поселении Мергень 7 в Приишимье из 58 сосудов козловского керамического комплекса наплывы присутствуют на $42(72,4 \%)^{82}$. В Притоболье на поселении ЮАО 15 на Андреевском озере наплывы с внутренней стороны на козловской посуде комплексов жилищ 1, 3, 4 и 6 распределяются следующим образом - 53,8; 56; 26,6 и 41,7\% соответственно ${ }^{83}$. В Среднем Зауралье на памятнике Евстюниха 1, по мнению А.А. Герасименко, выделяются два керамических комплекса, собственно евстюнихинский и полуденковский, составляющие 91 и 32 сосуда соответственно. По количеству наплывов на полуденковских сосудах нет данных, на евстюнихинской посуде «с внутренней стороны венчика обязательно присутствует наплыв» ${ }^{84}$. На посуде всех перечисленных выше комплексов с круглодонной керамикой, как правило, находятся наплывы с внутренней стороны венчика, а карнизики и валики отсутствуют (рис. 4, 1-9).



Рис. 4. Круглодонная керамика с наплывами. 1-9 - ЮАО 18 («VIII пункт») 
По нашим наблюдениям, взаимодействие аборигенного и пришлого населения, которое, на наш взгляд, могло выражаться, в частности, в переносе некоторых рельефных элементов с берестяной на глиняную посуду, имело системный характер и протекало в три фазы. На первой отмечается формирование под краем венчика карнизиков с внешней и внутренней стороны и небольших наплывов с внутренней стороны сосуда (количество этих элементов по данным с Юртобора 3 составляет 7,3\%). В дальнейшем в процессе взаимодействия фиксируется уже перенос элементов на тулово сосуда и продолжает формироваться верхняя часть венчика. Так, в комплексах, включающих несколько типов посуды, на сатыгинской присутствует один или несколько валиков, расположенных под краем венчика и на тулове, на посуде кошкинского типа появляются различные вариации (имеются в виду утолщения) края венчика. На этом этапе взаимодействия мы видим количественное увеличение рельефных элементов: так, валиков присутствует на Сумпанье 4 - 33,3, или $21,7 \%$, на Сумпанье 6 - 3,9\%, на Нижнем Озере 3 - 31,1\%, на Мергене 6 - 21,3\% (т.е. практически на $1 / 3$ и 1/4 посуды). В комплексах поселений с круглодонной посудой на смену различным вариантам утолщения края венчика и валикам приходят наплывы с внутренней стороны венчика, которые меняют свою форму и размеры. Количество наплывов на посуде разных памятников различается: в некоторых случаях их насчитывается от $1 / 4$ до более чем половины количества сосудов, на поселении Евстюниха 1 в раннем комплексе они составляют около 100\%. В поздненеолитических (сосновоостровских) комплексах (рис. 5, 1-8) наплывы единичны и менее массивны.

Начиная с раннего времени по краю венчика некоторых сосудов всех рассматриваемых комплексов отмечаются направленные вверх небольшие выступы - «ушки», возможно, имитирующие места крепления (?) ручек на берестяных аналогах. В ранних комплексах с плоскодонной и круглодонной керамикой отмечается рельефный элемент в виде наплыва или валика в месте перехода от тулова к дну. На прикаспийской посуде этот элемент встречается в единичных случаях, на рассматриваемой зауральской территории чаще. Однозначно говорить о придонных элементах как о перенесенных с берестяной посуды на керамику, вероятно, нельзя, поскольку оформление дна берестяной емкости, предназначенной для жидкости, иное, в виде «конверта». Являются ли валики чисто технологическим элементом, однозначно утверждать также нельзя, но отметим, что их количество на посуде зауральских комплексов, по сравнению с прикаспийскими материалами, где они единичны, увеличено. Нельзя исключать, что придонные элементы в виде валиков могли переноситься с берестяных емкостей, предназначавшихся для хранения не жидких, а сыпучих материалов. Понятно, что берестяная емкость, у которой в придонную часть вшит обруч, не способна удерживать жидкость, другое дело - керамический сосуд, материал которого обладает водонепроницаемостью.

Наряду с рельефными элементами на глиняной посуде ранних комплексов присутствуют орнаменты в виде вдавлений, наколов, возможно, имитирующих крепления обручей на берестяных емкостях. Они отмечаются в верхней части венчика, на тулове и в придонной части и на валиках. Вместе с тем не исключено, что волнистые линии, выполненные прочерчиванием и отступанием, нанесенные по верхнему краю наплыва с внутренней стороны сосуда комплексов с круглодонной посудой, воспроизводят уже не только или не столько крепление обруча; можно предположить, что этот мотив имеет уже скорее семантическое наполнение и связан с образом воды (волны) как основного содержимого сосуда.

В процессе взаимодействия аборигенного населения и мигрантов в плане формирования части западно-сибирской керамики можно проследить начальную фазу, пик (наивысшую точку развития) и завер- 



Рис. 5. Сосновоостровская керамика.

1, 6 - Серебрянка 1; 2-5, 7, 8 - ЮАО 18 («VIII пункт»)

шение - фазу спада. Это относится как к рельефным элементам (карнизики, валики и наплывы), так и формам сосуда в целом и орнаментам. Профилированным горшкам с придонными валиками, украшенными насечками, приходят на смену круглодонные сосуды (отмечаются «переходные» формы, с плоским приплюснутым дном, без валика). Отступающе-прочерченная техника нанесения узора постепенно сменяется гребенчатой. С данным процессом связан еще один очень важный, на наш взгляд, момент - формирование многокомпонентных комплексов с различными типами посуды.

Так, например, на поселении Юртобор 3 наряду с основным керамическим материалом, который сопоставим с боборыкинской посудой, присутствуют единичные фрагменты, близкие керамике басьяновского, кошкинского и гребенчатого типов. Более поздние керамические комплексы содержат в разном соотношении перечисленные выше типы посуды. Однако типов керамики на территории Западной Сибири в рассматриваемый период выделено значительно больше (вышеназванные, а также амнинский, каюковский и др.). Эта ситуация напоминает нам так называемые переходные археологические периоды, когда при взаимодействии двух или нескольких групп населения формируются разнообразные типы посуды, образующие единый комплекс. В нашем случае речь идет о взаимодействии культур аборигенов и мигрантов, в рамках 



Рис. 6. Современные и археологические берестяные изделия.

1 - из погребения эпохи бронзы. Хакасия (Эрмитаж); 2 - современное изделия; 3 - из Усть-Полуя (по: Декорированные изделия..., 2013; Могрицкая, 2018)

которого, видимо, происходил поиск пути дальнейшего развития симбиозной культуры, в том числе гончарного производства. Этот процесс наглядно, на наш взгляд, отражают многие комплексы, среди которых, например, Нижнее Озеро 3: в нем группы сатыгинской, кошкинской и смешанной, с гребенчато-прочерченно-накольчатой орнаментацией, посуды трактуются «как разные типы керамики, сосуществовавшие в рамках одного социума» ${ }^{85}$.

Однако на следующем этапе уже не фиксируется разнообразие типов керамики на одном поселении, развитие отражают комплексы с круглодонной посудой и с наплывами с внутренней стороны венчика: козловские, евстюнихинские, кокшаровскоюрьинские и полуденковские. На наш взгляд, на этом этапе завершается становление уже собственно местного керамического производства: боборыкинский, сатыгинский типы керамики исчезают. В круглодонной посуде с наплывами с внутренней стороны венчика просматриваются кошкинские черты и черты гребенчатого типа посуды в орнаментации, в наплывы могли трансформироваться 
рельефные элементы, перенесенные с берестяных емкостей.

Наряду с предполагаемой нами адаптацией рельефных элементов на неолитической посуде наблюдается изменение орнаментальной схемы: сокращается количество неорнаментированных емкостей и сосудов с геометрическими узорами, трансформируется орнамент, созвучный солярной и растительной символике, и возрастает количество простых линейных элементов.

Достаточно полно орнаменты и орнаментальные композиции на посуде боборыкинской культуры (под боборыкинскими мы понимаем комплексы боборыкинского и кошкинского этапов, в статье равнозначные комплексу с плоскодонной и круглодонной посудой) горнолесного и лесостепного Зауралья представлены в монографии В.Т. Ковалевой и С.Ю. Зыряновой ${ }^{86}$. Можно разделить орнаменты и их композиции на собственно принесенные, «приобретенные» в процессе взаимодействия и нейтральные, которые сложно интерпретировать. Принесенные - в основном немногочисленные орнаменты с солярной и растительной символикой на посуде комплекса с плоскодонной и круглодонной посудой, а также геометрические узоры в виде различных вариантов треугольников, овалов, меандров, ромбов и некоторых неопределимых фигур на тулове сосуда и орнаменты в виде кругов, спиралей, крестов, сетки и пр., помещенные на плоские днища сосудов ${ }^{87}$. $\mathrm{«приоб-}$ ретенным» (или адаптированным) можно отнести узоры, в частности, на венчике и в придонной части сосудов. Это прежде всего ряды прямых или наклонных насечек, зигзагов, косых крестов, иногда нанесенных на валики и наплывы (имитация крепления формообразующих обручей), две параллельные прямые, возможно, воспроизводящие валик, перечеркнутые наклонными отрезками влево 88 . Значительное количество орнаментов на плоскодонной и круглодонной посуде имеет вид горизонтальных зигзагов, а иногда через определенные про- межутки из их опущенных углов нанесены вертикальные зигзаги в различных вариантах и технике исполнения. К адаптированным можно отнести и растительные узоры на сосудах с круглодонной посудой, «унаследованные», по нашему мнению, от более ранних комплексов.

\section{Заключение}

Вопросы становления неолита и появления керамики в Западно-Сибирском регионе не утрачивают актуальности и важны для понимания особенностей развития не только неолита, но и комплексов последующих эпох. Исследователи не единодушны в обсуждении этих вопросов. Мы считаем, что керамическое производство сформировалось при прямом взаимодействии мигрантов из южных областей и еще не знавшего гончарства аборигенного населения Западной Сибири ${ }^{89}$, и предлагаем в этот сценарий внести немаловажный, на наш взгляд, возможный сюжет, связанный с имитацией переносом формообразующих элементов с берестяных емкостей на глиняную посуду.

На разных этапах выше обозначенного взаимодействия, которое рассматриваем как систему, отмечаются определенные формы и количество рельефных элементов на керамике. В некоторых ранних, повидимому, комплексах с плоскодонной и круглодонной посудой рельефные элементы отсутствуют: например, на поселениях Пикушка 1 и Мергень 3, на керамике других (Юртобор 3) фиксируются небольшие наплывы $(2,9 \%)$ и карнизики $(4,4 \%)$.

В многокомпонентных комплексах, с несколькими керамическими типами (боборыкинский, кошкинский, сатыгинский и др.), в разных количествах отмечаются различные варианты формы верхнего края венчика и небольшие наплывы с внутренней стороны под краем венчика, а также валики. Последние присутствуют на разных памятниках: на Сумпанье 4 (до 33,3\%), Сумпанье 6 (3,9\%), Нижнем Озере 3 (31,1\%), Мергене 6 (21,3\%), т.е. практически на трети или четверти всей посуды. 
На следующем этапе развития неолита, в комплексах памятников кокшаровскоюрьинского, евстюнихинского, козловского, полуденковского и, на наш взгляд, еттовского типа, вся посуда уже круглодонной формы, с достаточно массивными наплывами с внутренней стороны венчика. На поселении Мергень 7 наплывы присутствуют на $72,4 \%$ сосудов козловского керамического комплекса. В Притоболье на поселении ЮАО 15 наплывы с внутренней стороны венчика на козловской посуде жилищ 1,3 , 4 и 6 распределяются следующим образом - 53,8; 56; 26,6 и 41,7\% соответственно. На памятнике Евстюниха 1 на евстюнихинской посуде «с внутренней стороны венчика обязательно присутствует наплыв» ${ }^{90}$. На посуде всех комплексов с круглодонной керамикой, как правило, имеются наплывы с внутренней стороны венчика, а карнизики и валики отсутствуют. В поздненеолитических (сосновоостровских) комплексах наплывы единичны и менее массивны.

Рассмотренное изменение рельефных элементов во времени, в нашем представлении, может отражать особенности формирования местного керамического производства, вероятно, определившие своеобразие западно-сибирской неолитической посуды.

\section{ПРИМЕЧАНИЯ}

${ }^{1}$ Чернещов B.Н. К вопросу о сложении уральского неолита // История, археология и этнография Средней Азии. М.: Наука, 1968. С. 41-53.

${ }^{2}$ Сальников К.B. Новый вариант раннебронзовой культуры Зауралья // КСИА. М., 1961. Вып. 85. C. 3-10.

${ }^{3}$ См., например: Молодин В.И., Ненахов Д.А., Мыльникова Л.Н., Райнхольд С., Пархомчук Е.В., Калинкин П.Н., Пархомчук В.В., Растигеев С.А. Радиоуглеродное датирование комплекса эпохи раннего неолита памятника Тартас-1 (Среднее Приомье) с использованием установки «Ускорительный масс-спектрометр ИЯФ СО РАН» // Археология, этнография и антропология Евразии. Том 47. № 1. 2019. С. 15-22; Piezonka H., Kosinskaya L., Dubovtseva E., Chemyakin Y., Enshin D., Hartz S., Kovaleva V., Panina S., Savchenko S., Skochina S., Terberger T., Zakh V., Zhilin M., Zykov
$A$. The emergence of hunter-gatherer pottery in the Urals and West Siberia: New dating and stable isotope evidence // Journal of Archaeological Science. 2020. № 116. P. 1-19.

${ }^{4}$ Цетлин Ю.Б., Петрова Н.Ю. Ближний и Дальний Восток: общее и особенное двух центров происхождения гончарства // РА. 2020. № 1. С. 32-43.

${ }^{5}$ Бадер О.Н. Уральский неолит // МИА. 1970. № 166. C. $157-171$.

${ }^{6}$ Там же. С. 159.

${ }^{7}$ Косинская Л.Л. Неолит севера Западной Сибири: Генезис и связи // Тверской археологический сборник. Тверь: Изд-во ТГОМ, 2002. Вып. 5. С. 215-223.

${ }^{8}$ Там же. С. 222.

${ }^{9}$ Молодин В.И., Райнхольд С., Мыльникова Л.Н., Ненахов Д.А., Хансен С. Радиоуглеродные даты неолитического комплекса памятника Тартас-1 (ранний неолит в Барабе) // Вестник НГУ. Сер. История, филология. 2018. Т. 17. № 3: Археология и этнография. С. 39-56.

${ }^{10}$ Ковалева В.T. Неолит Среднего Зауралья. Свердловск: Изд-во УрГУ, 1989. 80 с.

${ }^{11}$ Ковалева В.Т., Зырянова С.Ю. Неолит Среднего Зауралья: Боборыкинская культура. Екатеринбург: Учеб. книга, 2010. 308 с.

${ }^{12}$ Зах B.A. Хроностратиграфия неолита и раннего металла лесного Тоболо-Ишимья. Новосибирск: Наука, 2009. 320 с.

${ }^{13}$ См., например: Маев Е.Г. Фазы мангышлакской регрессии Каспийского моря // Вестн. Моск. унта. Сер. 5. География. 2009. № 1. С. 15-20; Янина T.A., Сорокин B.М., Хошраван Г. Эволюция природной среды Каспия в условиях глобального изменения климата // Океанологические исследования. 2019. Том 47. № 5. С. 160-176.

${ }^{14}$ Морозов В.М., Стефанов В.И. Амня 1 - древнейшее городище Северной Евразии? // ВАУ. Екатеринбург: Изд-во УрГУ, 1993. Вып. 21. С. 143-170.

${ }^{15}$ Косинская Л.Л. Неолит Надым-Пуровского водораздела: источники и проблематика // Вестник Томского государственного университета. История. 2013. № 3 (23). С. 240-245.

${ }^{16}$ Шевнина И.В. Керамика эпохи неолита Тургайского прогиба. Автореф. дис. ... канд. ист. наук. Кемерово, 2019. 33 с.

${ }^{17}$ См., например: Мери В.К. Боборыкинский комплекс поселения Борлы (Северо-Восточный Казахстан) // Труды III (XIX) Всероссийского археологического съезда. Т. І. СПб. - Великий Новгород: ИИМК РАН, 2011. С. 297-301; Кирю- 
шин К.Ю., Кирюшин Ю.Ф. Керамика боборыкинского облика с поселений юго-западных районов Алтайского края // Теория и практика археологических исследований. № 2 (14). Барнаул: Изд-во АГУ, 2016. С. 7-23.

18 Зах В.А. Эпоха неолита и раннего металла лесостепного Присалаирья и Приобья. Тюмень: Изд-во ИПОС СО РАН, 2003. 168 с.

${ }^{19}$ Бобров В.В., Марочкин А.Г., Юракова А.Ю. Поселение боборыкинской культуры Автодром 2/2 (северо-западные районы барабинской лесостепи) // Вестник археологии, антропологии и этнографии. 2012. № 3. С. 4-13.

${ }^{20}$ Зах В.А., Еньшин Д.Н. К вопросу о неолитизации в лесостепи Западной Сибири // Вестник Кемеровского государственного университета. 2015. № 2 (62). T. 6. С. 34-43.

${ }^{21}$ Ковалева В.T. Неолит Среднего Зауралья..., 1989. С. 39.

${ }^{22}$ См., например: Хлобыстин Л.П. Сатыгинский тип керамики Западной Сибири // AD POLUS. Apxeологические изыскания. СПб. Фарн, 1993. Вып. 10. С. 29-35; Шорин А.Ф., Вилисов Е.В., Шорина А.А. Басьяновский археологический комплекс эпохи позднего неолита: основания выделения // РА. 2015. No 1. С. 5-18; Чаиркина Н.М., Дубовцева Е.Н. Керамика сатыгинского типа поселения Нижнее озеро III // Вестник археологии, антропологии и этнографии. 2016. № 1 (32). С. 19-31.

${ }^{23}$ Зах В.А. Хроностратиграфия ..., 2009. 320 с.

${ }^{24}$ См., например: Поселение Быстрый Кульеган 66: памятник эпохи неолита Сургутского Приобья / Коллективная монография под ред. Л.Л. Косинской и А.Я. Труфанова. Екатеринбург Сургут: Уральское изд-во, 2006. 192 с.; Панфилов А.Н. Многослойное поселение Серебрянка 1 в Нижнем Приишимье (Итоги полевых исследований). Тюмень: Изд-во ИПОС СО РАН, 1993. 80 с.; Бобров В.В., Марочкин А.Г. Хроностратиграфия неолитических комплексов поселения Автодром 2 // Проблемы археологии, этнографии, антропологии Сибири и сопредельных территорий. Новосибирск: Изд-во ИАЭТ СОРАН, 2011. Т. 17. С. 14-19.

${ }^{25}$ См., например: Зах В.A. Появление керамики в Западной Сибири (к обсуждению проблемы) // Вестник археологии, антропологии и этнографии. 2018. № 4 (43). С. 20-31; Piezonka H. et $a l$. The emergence of hunter-gatherer ..., 2020. № 116. Р. 1-19; Молодин и др. Радиоуглеродное датирование комплекса ..., 2019.

${ }^{26}$ См., например: Ковалева В.Т., Зырянова С.Ю.
Неолит Среднего ..., 2010. 308 с.; Чаиркина H.M., Дубовиева Е.Н. Керамические комплексы эпохи неолита поселения Нижнее озеро III // Вестник археологии, антропологии и этнографии. 2014. № 1 (24). С. 4-13; Чаиркина H.M., Дубовцева Е.Н. Керамика сатыгинского ..., 2016. № 1 (32). С. 19-31; Морозов B.M., Cтефанов В.И. Амня 1 - древнейшее городище ..., 1993. С. 143-170; Сладкова Л.Н. Чертова Гора неолитический памятник в бассейне Конды // ВАУ. Екатеринбург: Изд-во УрГУ, 2008. Вып. 25. С. 147-158; Шорин А.Ф., Вилисов Е.В., Шорина $A . A$. Басьяновский археологический комплекс ..., 2015. № 1. С. 5-18; Панина С.Н., Пиецонка Х., Харти 3., Тербергер Т. Жертвенное место с керамикой сатыгинского типа эпохи неолита на Усть-Вагильском холме (Средний Урал, Россия) // V Северный археологический конгресс: Тезисы докладов. Ханты-Мансийск; Екатеринбург, 2019. С. 118-121.

${ }^{27}$ См., например: Зах В.А., Зимина О.Ю., Рябогина H.E. Радиоуглеродные даты археологических и природных комплексов Тоболо-Ишимья (по материалам Тоболо-Ишимской экспедиции ИПОС СО РАН) // Вестник археологии, антропологии и этнографии. 2011. № 1 (14). С. 219-233; Еньшин Д.Н. Керамический комплекс поселения Мергень 7 (Нижнее Приишимье): характеристика и интерпретация // Вестник археологии, антропологии и этнографии. 2015. № 2 (29). С. 15-27; Герасименко А.А. Характеристика керамики поселения Евстюниха 1 // ВАУ. Екатеринбург: Изд-во УрГУ, 2008. Вып. 25. С. 44-72; Косинская Л.Л. Неолит Надым-Пуровского водораздела ..., 2013. № 3 (23). С. 240-245; Зах В.А. Эпоха неолита и раннего ..., 2003. 168 с.

${ }^{28}$ Декорированные изделия обских угров из фондов Тюменского областного Музейного комплекса им. И.Я. Словцова / Сост. Т.Н. Рафикова, К.Н. Барабанщиков. Под ред. В.Н. Адаева. Тюмень: Тюменский издательский дом, 2013. 76 с.

${ }^{29}$ Могрицкая В.Ю. Орнаментированные берестяные изделия Усть-Полуя (І в. до н.э. - І в. н.э.) // Археология, этнография и антропология Евразии. 2018. Т. 46. № 1. С. 51-58.

${ }^{30}$ Глушков И.Г. Керамика как исторический источник. Новосибирск: ИАЭТ СО РАН, 1996. 328 с.

${ }^{31}$ Глушков И.Г., Глушкова Т.Н. Текстильная керамика как исторический источник. Тобольск, $1992.130 \mathrm{c}$.

${ }^{32}$ Глушков И.Г. Керамика как исторический источник ... С. 68. 
${ }^{33}$ Бородовский А.П. К вопросу о керамике, имитирующей швы кожаной посуды (по материалам курганной группы Быстровка 1) // Археологические памятники лесостепной полосы Западной Сибири. Новосибирск: НГПИ, МП РСФСР, 1983. С. 51-56.

${ }^{34}$ Комарова М.Н. Неолит Верхнего Приобья // КСИИМК. 1956. Вып. 64. С. 93-103.

35 Зах В.А. Эпоха неолита и раннего ..., 2003. C. 129.

36 Зах В.А. Хроностратиграфия ..., 2009. С. 170.

${ }^{37}$ Мыльникова Л.Н., Молодин В.И., Бобров В.В., Стефанов В.И. Керамика эпохи раннего неолита Западной Сибири (результаты термического анализа) // Уральский исторический вестник. Екатеринбург, 2019. № 4 (65). С. 17-29.

38 Зах В.А., Фомина Е.А. К вопросу о происхождении андреевской культуры // Вестник археологии, антропологии и этнографии. 1999. Вып. 2. C. 14-21.

${ }^{39}$ См., например: Ковалева В.Т. Взаимодействие культур и этносов по материалам археологии: поселение Ташково 2. Екатеринбург: Изд-во УрГУ, 1997. 131 с.; Молодин В.И. Эпоха неолита и бронзы лесостепного Обь-Иртышья. Новосибирск: Наука, 1977. 173 с.; Зах В.А. Поселок древних скотоводов на Тоболе. Новосибирск: Наука, 1995.96 с.

${ }^{40}$ Зах B.A. Городище Ласточкино Гнездо в Нижнем Приишимье // Вестник археологии, антропологии и этнографии. 2009. Вып. 11. С. 67-80.

${ }^{41}$ Ryabogina N.E., Afonin A.S., Ivanov S.N., Li H.C., Kalinin P.A., Udaltsov S.N., Nikolaenko S.A. Holocene paleoenvironmental changes reflected in peat and lake sediment records of Western Siberia: Geochemical and plant macrofossil proxies // Quaternary International. 2019, Vol. $528,73-87$.

${ }^{42}$ Зах В.А. Боборыкинский комплекс поселения Юртобор 3 в Нижнем Притоболье // Древняя и современная культура народов Западной Сибири / Отв. ред. А.П. Зенько. Тюмень: ТюмГУ, 1995. С. 12-28.

${ }^{43}$ Петрин В.Т. Палеолитические памятники Западно-Сибирской равнины. Новосибирск: Наука, 1986. 143 с.

${ }^{44}$ Зенин В.И. Основные этапы освоения Западно-Сибирской равнины палеолитическим человеком // АЭАЕ. Новосибирск: Изд-во ИАЭТ, 2002. № 4. C. 22-44.

${ }^{45}$ Петрин В.Т. Палеолитические памятники ..., 1986.
${ }^{46}$ Осинцева Н.В. Гривный рельеф юга западносибирской равнины: морфология и возраст (на примере черноозерской гривы, саргатское Прииртышье) // Геосферные исследования. 2017. № 3. C. 26-32.

${ }^{47}$ См., например: Сериков Ю.Б. Некоторые итоги изучения мезолита на территории Среднего Зауралья. // ВАУ. Екатеринбург: Изд-во УрГУ, 1991. Вып. 20. С. 23-30; Беспрозванный Е.M. Мезолит таежной зоны Западной Сибири (Предварительные итоги изучения) // Охранные археологические исследования на Среднем Урале. Екатеринбург: «Екатеринбург», 1997. Вып. 1. С. 26-38; Крижевская Л.Я. Мезолитическое поселение Ташково 4 и некоторые общие вопросы мезолита Урала // ВАУ. Екатеринбург: Изд-во УрГУ, 1991. Вып. 20. С. 30-45; Стоянов В.Е., Крижевская Л.Я., Старков В.Ф. Мезолитическая стоянка Сухрино 1 на Исети // Археологические исследования на Урале и Западной Сибири. Свердловск: Изд-во УрГУ, 1977. С. 72-84; Генинг В.Ф., Петрин В.Т., Косинская Л.Л. Первые поселения эпохи позднего палеолита и мезолита в Западной Сибири // ИИС. Томск: Изд-во ТГУ, 1973. Вып. 5. С. 24-47.

${ }^{48}$ Беспрозванный Е.М. Первые мезолитические жилища в таежной зоне Западной Сибири // Проблемы древних культур Сибири. Новосибирск: Изд-во ИИФФ СО АН СССР, 1985. С. 91-95.

${ }^{49}$ См., например: Зах B.A. Боборыкинский комплекс ..., 1995; Тимофеев В.И., Зайцева Г.И. Проблемы абсолютной хронологии // Археология. Неолит Северной Евразии. М.: Наука, 1996. С. 345-354.

${ }^{50}$ Мелларт Дж. Древнейшие цивилизации Ближнего Востока. М.: Наука, 1982. 150 с.

${ }^{51}$ Там же. С. $87,88$.

${ }^{52}$ Сладкова Л.Н. Чертова Гора - неолитический ..., 2008.

${ }^{53}$ См., например: Кулемзин В.М., Лукина Н.В. Васюганско-Ваховские ханты в конце XIX - XX вв. Этнографические очерки. Томск: Изд-во ТГУ, 1977. 226 с.

${ }^{54}$ Бадер О.Н. Уральский ..., 1970. С. 159.

${ }^{55}$ Виноградов А.В. Древние охотники и рыболовы Среднеазиатского междуречья. М.: Наука, 1981. С. 66. Рис. 20.

${ }^{56}$ Ковалева В.Т., Зырянова С.Ю. Неолит ... С. 283.

${ }^{57}$ Ковалева В.Т. Неолит Среднего ... С. 35.

${ }^{58}$ Зах В.А. Хроностратиграфия неолита ..., 2009.

${ }^{59}$ Ковалева В.Т., Зырянова С.Ю. Неолит ..., 2010.

${ }^{60}$ Там же. С. 237. 
${ }^{61}$ Там же. С. 243.

62 Там же. С. 290.

63 Зах В.А. Хроностратиграфия неолита ... С. 159.

${ }^{64}$ См., например: Ковалева В.Т., Зырянова С.Ю. Неолит ..., 2010; Чаиркина Н.М., Дубовцева Е.Н. Керамические комплексы ..., 2014; Чаиркина H.M., Дубовцева Е.Н. Керамика сатыгинского ..., 2016; Еньшин Д.Н. К проблеме интерпретации некоторых локальных типов керамики в контексте боборыкинской проблематики (горно-лесное Зауралье, таежная и лесостепная зоны Западной Сибири) // V Северный археологический конгресс: Тезисы докладов. Ханты-Мансийск; Екатеринбург, 2019. С. 82-84.

${ }^{65}$ Чаиркина Н.M., Дубовцева Е.Н. Керамика сатыгинского ..., 2016. С. 19.

${ }^{66}$ См., например: Васильев И.Б., Выборнов А.А., Козин E.B. Поздненеолитическая стоянка Тентексор в Северном Прикаспии // Древние культуры Северного Прикаспия. Куйбышев: Изд-во КГПИ, 1986. С. 6-31; Кольцов П.М. Неолитическое поселение Джангар // Археологические культуры Северного Прикаспия. Куйбышев: Изд-во КГПИ, 1988. С. 52-92; Мелентьев А.Н. Памятники сероглазовской культуры (Неолит Северного Прикаспия) // КСИА. 1975. Вып. 141. С. 112-117; Выборнов А.А., Козин Е.В. Неолитическая стоянка Каиршак 1 в Северном Прикаспии // Apхеологические культуры Северного Прикаспия. Куйбышев: Изд-во КГПИ, 1988. С. 92-122.

${ }^{67}$ См., например: Юдин А.И. Варфоломеевская неолитическая стоянка // Археологические культуры Северного Прикаспия. Куйбышев: Изд-во КГП, 1988. С. 142-172; Васильев И.Б., Выборнов А.А. Неолит Поволжья (степь и лесостепь): Учебное пособие к спецкурсу. Куйбышев: Изд-во КГПИ, 1988. Рис. 17, 19, 20.

${ }^{68}$ Мери В.К. Боборыкинский комплекс ..., 2011.

${ }^{69}$ Кирюшин К.Ю., Кирюшин Ю.Ф. Керамика боборыкинского ..., 2016. Рис. 3.

${ }^{70}$ Мери B.K. Некоторые итоги и перспективы изучения археологических памятников Павлодарского Прииртышья // Изучение памятников Павлодарского Приртышья. Павлодар: НПФ «Эко», 2002. С. 5-20.

71 Чалая Л.А. Озерные стоянки Павлодарской области. Пеньки 1, 2 // Поиски и раскопки в Казахстане. Алма-Ата: Наука, 1972. С. 163-181.

${ }^{72}$ Шевнина И.В. Керамика эпохи неолита ..., 2019. C. 30 .

${ }^{73}$ См., например: Коновалов А.А. Общие черты развития экогеосистем // Проблемы взаимо- действия человека и природной среды. Тюмень: Изд-во ИПОС СО РАН, 2000. Вып. 1. С. 143-146; Коновалов А.А. Энергетика экогеосистем // Проблемы взаимодействия человека и природной среды. Тюмень: Изд-во ИПОС СО РАН, 2001. Вып. 2. С. 124-127; Коновалов А.А. Физический смысл и типология устойчивости экогеосистем // Проблемы взаимодействия человека и природной среды. Тюмень: Изд-во ИПОС СО РАН, 2003. Вып. 4. С. 153-157.

${ }^{74}$ Зах В.А. Боборыкинский комплекс ..., 1995. Рис. 1, 7, 3, 5.

${ }^{75}$ Хлобыстин Л.П. Сатыгинский тип керамики ..., 1993.

${ }^{76}$ См., например: Крижевская Л.Я., Гаджиева Е.А. Неолитическое поселение Сумпанья и его место в неолите Восточного Зауралья // Неолитические памятники Урала. Свердловск, 1991. С. 80-99; Ковалева В.Т., Зырянова С.Ю. Неолит ... C. 195.

${ }^{77}$ Ковалева В.Т., Устинова Е.А., Хлобыстин Л.П. Неолитическое поселение Сумпанья 4 в бассейне Конды // Древние поселения Урала и Западной Сибири. Свердловск: УрГУ, 1984. С. 32-44.

${ }^{78}$ Хлобыстин Л.П. Сатыгинский тип керамики ..., 1993. С. 30.

${ }^{79}$ См., например: Чаиркина Н.M., Дубовцева Е.Н. Керамические комплексы ..., 2014; Чаиркина H.M., Дубовцева Е.Н. Керамика сатыгинского ..., 2016.

${ }^{80}$ Еньшин Д.Н. К проблеме интерпретации ..., 2019.

${ }^{81}$ Косинская Л.Л. Неолит Надым-Пуровского ..., 2013.

${ }^{82}$ Еньшин Д.Н. Керамический комплекс поселения ..., 2015. С. 17.

${ }^{83}$ Асташкин В.И. Орнаментальные традиции и некоторые проблемы культурной эволюции в неолите Зауралья // Проблемы культурогенеза и культурное наследие. Ч. 2. Археология и изучение культурных процессов и явлений. СПб., 1993. С. 54-59.

${ }^{84}$ Герасименко А.А. Характеристика керамики поселения ..., 2008. С. 51, 53.

85 Чаиркина Н.М., Дубовцева Е.Н. Керамические комплексы ..., 2014. С. 12.

${ }^{86}$ Ковалева В.Т., Зырянова С.Ю. Неолит ... Табл. 9, 14.

${ }^{87}$ Там же. Табл. 9, 10.

${ }^{88}$ Там же. Табл. 9, 199.

89 Зах В.А. Хроностратиграфия неолита ..., 2009.

90 Герасименко А.А. Характеристика керамики поселения ..., 2008. 


\section{ON SOME ASPECTS OF THE FORMATION \\ OF EARLY NEOLITICAL TABLEWARE IN WESTERN SIBERIA}

(C) 2020 V.A. Zakh

\section{FRC Tyumen Scientific Center SB RAS}

Issues of the origins and development of pottery are actualized through a study of new Early Neolithic forest-steppe and taiga sites in Western Siberia. The flat-bottomed and roundbottomed Neolithic dishes found in Western Siberia are similar in shape and ornamentation. They seem to be a continuation of an earlier ceramic tradition that was introduced into the region. Based upon the radiocarbon dates, those dishes appeared in West Siberia within the 7th millennium BC. We adhere to the opinion that the local population borrowed ceramic production from migrants and believe that imitation of structural parts of birch bark containers in ceramic vessels was important for the formation of West Siberian pottery. For example, such sculptured elements as ledges, drips, and moldings on the outer and inner sides of the rims of ceramic vessels can be correlated to the bands on birch bark dishes and their fastening elements. In our opinion, sculptured elements on ceramic dishes gradually transformed into semantic elements: wavy lines (zigzags) on the drips on the inner side of the rim not only refer to a band attached to the vessel but apparently represent water (waves) as the contents of the vessel.

Keywords: Western Siberia, Tobol-Ishim interfluve, Neolithic, flat-bottomed and roundbottomed dishes, ledges, moldings, drips on the inner side of the rim.

DOI: $10.37313 / 2658-4816-2020-2-4-102-121$

Victor Zakh, Doctor of History, Head of the Archaeological and Natural Reconstruction Sector. E-mail:viczakh@mail.ru 